\title{
PRZENIESIENIE SIEDZIBY POLSKIEJ SPÓŁKI KAPITALOWEJ ZA GRANICĘ JAKO PRZYCZYNA JEJ ROZWIAZZANIA W ŚWIETLE KODEKSU SPÓŁEK HANDLOWYCH I SWOBODY PRZEDSIĘBIORCZOŚCI
}

\section{WPROWADZENIE}

Już od wyroku Trybunału Sprawiedliwości ${ }^{1}$ w sprawie Sevic Systems nie budzi wątpliwości, że wszelkie postaci transgranicznej restrukturyz acji stanowią, ,szczególny sposób korzystania ze swobody przedsiębiorczości, istotny dla prawidłowego funkcjonowania rynku wewnętrznego" ${ }^{2}$. Z kolei judykaty Cartesio $^{3}$ i Vale potwierdzaja, że korzystanie ze swobody przedsiębiorczości może przybrać postać przekształcenia spółki w formę prawną spółki zagranicznej, która stanowi odpowiednik krajowej spółki przekształcanej (np. polska spółka z o.o. może przekształcić się w niemiecką GmbH) ${ }^{4}$.

Powszechnie oczekuje się wydania (czternastej) dyrektywy w sprawie transgranicznego przeniesienia siedziby statutowej spółki połaczonej ze zmiana jej dotychczasowego statutu personalnego ${ }^{5}$. Oczekiwanie to podziela także

${ }^{1}$ Wyroki Trybunału Sprawiedliwości UE (TSUE), wcześniej Europejskiego Trybunału Sprawiedliwości (ETS), dostępne są na: www.curia.europa.eu.

2 Teza 19 wyroku ETS z 13 grudnia 2005 r., C-411/03 (Sevic Systems). Do głównej tezy wyroku w sprawie Sevic Systems Trybunał nawiazał w tezie 24 wyroku z 12 lipca 2012 r., C-378/10 (Vale): „[...] co do zasady operacje przekształcenia spółek należą do zakresu działalności gospodarczej, w odniesieniu do której państwa członkowskie mają obowiązek respektować swobodę przedsiębiorczości”.

${ }^{3}$ Wyrok ETS z 16 grudnia 2008 r., C-210/06 (Cartesio).

${ }^{4}$ W. Schön, Das System der gesellschaftsrechtlichen Niederlassungsfreiheit nach VALE, ,Zeitschrift für Unternehmens- und Gesellschaftsrecht” 2013, z. 3, s. 345: „[...] bei den hier diskutierten Fällen grenzüberschreitender Umwandlung geht es in der Regel um einen »rechtsformkongruenten Formwechsel" zwischen inhaltlich weitgehend parallelen Gesellschaftstypen (GmbH in SARL, plc in AG etc.), dessen Regelung es im nationalen Recht überhaupt nicht bedarf, der vielmehr nur bei internationalen Sachverhalten durchgeführt werden kann".

${ }^{5}$ W.-G. Ringe, Corporate mobility in the European Union - a flash in the plan? An empirical study on the success of lawmaking and regulatory competition, „European Company and Financial Law Review" 2013, z. 2, s. 232. Potwierdzają to także wyniki przeprowadzonej przez Komisję UE konsultacji (Feedback statement. Summary of responses to the public consultation on crossborder transfer of registered offices of companies, September 2013). Wyniki konsultacji prezentuje O. Sachanbińska, Transgraniczne przeniesienie siedziby spótki kapitałowej - potrzeba dziatania unijnego i polskiego ustawodawcy, „Transformacje Prawa Prywatnego” 2015, z. 3, s. 85-86. 
Trybunał Sprawiedliwości ${ }^{6}$, który sam nie może - wypełniając na potrzeby konkretnego przypadku luki legislacyjne ustawodawcy unijnego ${ }^{7}$ - „tworzyć" unijnego prawa spółek bezpośrednio na mocy Traktatu ${ }^{8}\left(\mathrm{TfUE}^{9}\right)$. Planowana czternasta dyrektywa ma na celu urzeczywistnienie swobody przedsiębiorczości (art. 50 ust. 1 TfUE) poprzez znoszenie krajowych ograniczeń oraz ochronę interesów wierzycieli i wspólników (art. 50 ust. 2 lit. f i g TfUE).

Brak czternastej dyrektywy i brak krajowych przepisów o transgranicznym przekształceniu spółki prowokuje do pytania: Czy państwo członkowskie może uzależnić transgraniczne przekształcenie od wymogu przeprowadzenia przez spółkę procedury likwidacyjnej i jej rozwiązania? Na gruncie prawa polskiego taki wymóg przewidziany jest w art. 270 pkt 2 i art. 459 pkt 2 k.s.h., w myśl których uchwały wspólników (akcjonariuszy) o przeniesieniu siedziby spółki za granice sa przyczyna jej rozwiąania oraz prowadza do otwarcia likwidacji (art. $274 \S 1$ i art. $461 \S 1$ k.s.h.). W sprawie dotyczącej przekształcenia spółki polskiej w spółkę prawa luksemburskiego wątpliwość co do zgodności wymienionych przepisów Kodeksu spółek handlowych z art. 49 TfUE powzią Sąd Najwyższy, zadając TSUE pytanie prejudycjalne ${ }^{10}$. Poniższe uwagi zawierają próbę udzielenia odpowiedzi na postawione pytania dotyczace: a) zgodności art. 270 pkt 2 i art. i 459 pkt 2 k.s.h. z art. 49 i 54 TfUE, b) uznania obowiazku przeprowadzenia postępowania likwidacyjnego spółki przekształcanej jako środka usprawiedliwionego ważnymi potrzebami interesu publicznego (imperative requirements in the public interest) oraz c) konieczności przeniesienia za granicę siedziby głównego przedsiębiorstwa polskiej spółki przekształcanej.

\section{PRZEPISY OGRANICZAJĄCE SWOBODE PRZEDSIĘBIORCZOŚCI - ART. 270 PKT 2 K.S.H. I ART. 459 PKT 2 K.S.H.}

1. Uzależnienie wykreślenia z rejestru spółki przenoszącej swą siedzibę za granicę od jej rozwiązania (po przeprowadzeniu procedury likwidacyjnej) uniemożliwia przeprowadzenie transgranicznego przekształcenia spółki polegajacego na zmianie formy prawnej z zachowaniem dotychczasowego bytu prawnego (zasada kontynuacji). Stanowi ograniczenie swobody przed-

${ }^{6}$ Teza 38 zd. 2 wyroku TS z 12 lipca 2012 r., C-378/10 (Vale).

${ }^{7}$ M.-P. Weller, B. Rentsch, Die Kombinationslehre beim grenzüberschreitenden Rechtsformwechsel - Neue Impulse durch Europarecht, „Praxis des Internationalen Privat- und Verfahrensrechts" 2013, z. 6, s. 531.

${ }^{8}$ K. J. Hopt, Europäisches Gesellschaftsrecht im Lichte des Aktionsplans der Europäischen Kommission vom Dezember 2012, „Zeitschrift für Unternehmens- und Gesellschaftsrecht” 2013, nr 2, s. 213; W. Schön, op. cit., s. 337.

${ }_{9}$ Traktat o funkcjonowaniu Unii Europejskiej - wersja skonsolidowana (Dz. Urz. UE C 326 z 26 października 2012 r., s. 47); wcześniej TWE - Traktat ustanawiający Wspólnotę Europejską z 13 grudnia 2007 r. (Dz. Urz. UE L 306 z 17 grudnia 2007 r., s. 1).

${ }_{10}$ Postanowienie SN z 22 października 2015 r. (IV CSK 664/14). Por. także: postanowienie Sądu Okręgowego w Bydgoszczy z 4 czerwca 2014 r. (VIII Ga 3/14) oraz postanowienie Sądu Okręgowego w Bydgoszczy z 17 lipca 2015 r. (VIII Ga 121/15), http://www.orzeczenia.com.pl. 
siębiorczości, ponieważ zwiększa spółce koszty dostępu do rynku innego państwa członkowskiego. Przez stworzenie spółce krajowej możliwości transgranicznego przekształcenia - podobnie jak przez umożliwienie spółce udziału w transgranicznym połączeniu - „komplikacje, czas i koszty, które wiążą się z innymi formami konsolidacji spółek, takimi jak np. rozwiązanie spółki połączone z przeprowadzeniem likwidacji lub założenie nowej spółki połączone z przeniesieniem na nią części majątku, sa minimalizowane" ${ }^{11}$. Powstaje jednak pytanie: Czy ograniczenie korzystania przez spółkę ze swobody przedsiębiorczości przez wymóg przeprowadzenia procedury likwidacyjnej nie leży w gestii państwa członkowskiego, które - zdaniem Trybunału - może wpływać na podmiotowy zakres swobody przedsiębiorczości?

2. Problem autonomii państwa członkowskiego w określaniu podmiotowego zakresu swobody przedsiębiorczości został podniesiony w wyroku w sprawie Daily Mail ${ }^{12}$, rozwinięty w wyroku w sprawie Cartesio, a następnie potwierdzony w wyrokach National Grid Indus ${ }^{13}$ oraz Vale. Zdaniem Trybunału, aby orzec o tym, czy spółka krajowa może powołać się na zakaz ograniczania swobody przedsiębiorczości (a więc czy jest adresatem art. 49 TfUE), należy uprzednio ustalić, czy z perspektywy prawa krajow e g o spełnia ona przesłanki wymienione w art. 54 TfUE. Państwo członkowskie ma prawo do określenia „kryterium powiązania”, wymaganego od spółki „po to, by mogła ona zostać uznana za spółkę utworzoną zgodnie z jego prawem i w związku z tym mogąca cieszyć się swobodą przedsiębiorczości, jak również kryterium wymaganego do utrzymania tego statusu w przyszłości. W ramach tego uprawnienia mieści się możliwość, by to państwo członkowskie nie zgodziło się na zachowanie tego statusu przez spółkę podlegającą jego prawu krajowemu, jeżeli zamierza ona zreorganizować się w innym państwie członkowskim w taki sposób, by przenieść swoją siedzibę na jego terytorium, zrywając $\mathrm{w}$ ten sposób powiązanie przewidziane w prawie krajowym państwa członkowskiego, na podstawie którego została utworzona"14. Inaczej rzecz ujmujac: ,jedynie wtedy, gdy potwierdzi się, że taka spółka faktycznie może korzystać ze swobody przedsiębiorczości w świetle warunków określonych w art. 48 TWE [art. 54 TFUE], pojawia się pytanie o to, czy spółka ta jest objęta ograniczeniami tej swobody w rozumieniu art. 43 TWE [art. 49 TFUE]"15.

Wspomniane „kryterium powiązania” spółki mogą regulować zarówno krajowe przepisy prawa kolizyjnego, jak i materialnego. Może więc art. 270 pkt 2 i art. 459 pkt 2 k.s.h. wprowadzają tego rodzaju kryterium? Aby na to pytanie odpowiedzieć, należy dodać, że Trybunał Sprawiedliwości wskazał dwojakiego rodzaju granic ę autonomii państwa członkowskiego w określaniu podmiotowego zakresu swobody przedsiębiorczości.

11 Teza 21 wyroku ETS z 13 grudnia 2005 r., C-411/03 (Sevic Systems), 2005, s. I-10805 i teza 47 opinii Rzecznika Generalnego w tej sprawie.

${ }^{12}$ Wyrok ETS z 27 września 1988 r., 81/87 (Daily Mail).

13 Wyrok TSUE z 29 listopada 2011 r., C-371/10 (National Grid Indus).

14 Teza 110 wyroku ETS z 16 grudnia 2008 r., C-210/06 (Cartesio).

15 Teza 109 zd. 2 wyroku ETS z 16 grudnia 2008 r., C-210/06 (Cartesio). 
Po pierwsze - w wyroku w sprawie C-371/10 (National Grid Indus) Trybunał nie podzielił poglądu uczestniczących w postępowaniu przedstawicieli siedmiu rządów państw członkowskich co do jeszcze szerszego (niż wynika to z wcześniejszych wyroków) wpływu krajowego prawa na podmiotowy zakres swobody przedsiębiorczości ${ }^{16}$.

Po drugie - w sprawie Cartesio Trybunał stwierdził, że przepisy krajowe uniemożliwiające spółce przeniesienie siedziby faktycznej z zachowaniem dotychczasowej prawnej postaci i statutu personalnego nie naruszaja zakazu ograniczania swobody przedsiębiorczości ${ }^{17}$. Dodał jednak zarazem - i na to należy zwrócić uwage - że wspomniany wyżej wariant ekspansji gospodarczej „należy odróżnić od przypadku przeniesienia spółki podlegającej jednemu państwu członkowskiemu do innego państwa członkowskiego ze zmiana majaccego zastosowanie prawa krajowego, gdy spółka zmienia się w rodzaj spółki podlegający prawu krajowemu państwa członkowskiego, do którego się przenosi"18. Różnica między wspomnianymi postaciami korzystania przez spółkę ze swobody przedsiębiorczości polega na tym, że państwo członkowskie ni e może uniemożliwiać, ,jej przekształcenia się w spółkę prawa krajowego tego drugiego państwa członkowskiego, o ile jego prawo na to pozwala"19. Państwo członkowskie może więc przeciwstawić się funkcjonowaniu spółki poza granica pod dotychczasową flaga, nie może natomiast - poprzez wymóg jej rozwiązania - uniemożliwić ko n ty nu ow an ia działalności gospodarczej spółce, która zmienia swój dotychczasowy statut personalny (przekształca się w spółkę zagraniczna). Inaczej rzecz ujmując: przepisy art. 270 pkt 2 i art. 459 pkt 2 k.s.h byłyby zgodne z art. 49 TfUE przy założeniu, że stanowią one materialnoprawną konsekwencję polskiego prawa kolizyjnego hołdującego teorii siedziby rzeczywistej ${ }^{20}$. Obecnie jednak - zgodnie z powszechnym poglądem ${ }^{21}$ podzielanym przez sąd rejonowy i okręgowy w Bydgoszczy ${ }^{22}$ oraz niekwestionowanym przez zadający pytanie prejudycjalne Sąd Najwyższy - w polskim

${ }^{16}$ Teza 29 wyroku TSUE z 29 listopada 2011 r. w sprawie C-371/10 (National Grid Indus). Zdaniem rządów niderlandzkiego, niemieckiego, włoskiego, portugalskiego, fińskiego, szwedzkiego i Zjednoczonego Królestwa: jeśli państwo członkowskie ma kompetencję do wymagania rozwiazania i likwidacji emigrującej spółki, to państwo to powinno być również umocowane do nałożenia zobowiazań podatkowych, skoro umożliwia ono - co sprzyja rynkowi wewnętrznemu - przeniesienie siedziby z zachowaniem osobowości prawnej.

${ }^{17}$ Teza 107 wyroku ETS z 16 grudnia 2008 r., C-210/06 (Cartesio) z powołaniem się na tezę 70 wyroku ETS z 5 listopada 2002 r., C-208/00 (Überseering).

18 Teza 111 wyroku ETS z 16 grudnia 2008 r., C-210/06 (Cartesio).

${ }^{19}$ Teza 112 in fine wyroku ETS z 16 grudnia 2008 r., C-210/06 (Cartesio). Jeżeli więc w państwie przyjmującym została uregulowana określona postać restrukturyzacji spółki krajowej (krajowa fuzja, podział, przekształcenie spółki w inną formę prawna), to powinna być ona dostępna także dla spółek zagranicznych korzystających ze swobody przedsiębiorczości. Teza 33 wyroku TSUE z 12 lipca 2012 r., C-378/10 (Vale).

${ }^{20}$ Taki punkt wyjścia przyjmuje M. Spyra, Konsekwencje faktycznego przeniesienia siedziby spótki kapitałowej za granicę, w: Studia z prawa prywatnego gospodarczego. Księa pamiatkowa ku czci prof. Ireneusza Weissa, Kraków 2003, s. 285-298.

${ }^{21}$ Syntetycznie problem referuje A. W. Wiśniewski, W sprawie statutu personalnego osób prawnych. Uwagi na tle tomu 20A Systemu Prawa Prywatnego, „Kwartalnik Prawa Prywatnego” 2015, z. 1, s. 215-225.

${ }^{22}$ Por. przypis 10 
prawie kolizyjnym siedziba rzeczywista nie jest podstawowym łącznikiem wyznaczającym statut personalny spółki, a art. 270 pkt 2 i art. 459 pkt 2 k.s.h określają konsekwencje podjęcia uchwały o przeniesieniu za granicę siedziby statutowej spółki ${ }^{23}$ w celu jej transgranicznego przekształcenia ${ }^{24}$.

3. Zdaniem Trybunału Sprawiedliwości uniemożliwienie spółce przekształcenia się w spółkę prawa innego państwa członkowskiego stanowi ograniczenie swobody przedsiębiorczości, które jednak może być u s p r a w i e d li w i on e nadrzędnymi względami interesu ogólnego ${ }^{25}$. Szczególnej ochronie powinny podlegać interesy wspólników mniejszościowych, pracowników oraz interesy wierzycieli ${ }^{26}$, a ochrona wspomnianych interesów leży u podstaw art. 270 pkt 2 i art. 459 pkt 2 k.s.h. ${ }^{27}$

\section{CZY OGRANICZENIE SWOBODY PRZEDSIĘBIORCZOŚCI PRZEZ ART. 270 PKT 2 K.S.H. I ART. 459 PKT 2 K.S.H. JEST USPRAWIEDLIWIONE?}

\section{Wprowadzenie}

O usprawiedliwionym naruszeniu swobody przedsiębiorczości można mówić wówczas, gdy niedyskryminujące środki (przepisy) stosowane przez państwo członkowskie w imię godnych ochrony interesów spełniają test proporcjonalności, a więc: są właściwe (adekwatne) z punktu widzenia osiagnięcia zamierzonego przez nie celu oraz nie wykraczaja poza to, co jest niezbędne dla osiagnięcia tego celu (sa konieczne) ${ }^{28}$. W sprawie proporcjonalności art. 270 pkt 2 i art. 459 pkt 2 k.s.h. funkcjonują w polskiej literaturze przedmiotu dwa odmienne poglądy.

Zdaniem Macieja Mataczyńskiego art. 270 pkt 2 i art. 459 pkt 2 k.s.h. stanowią ograniczenie swobody przedsiębiorczości, ale jest to ograniczenie usprawiedliwione nadrzędnymi wymogami interesu publicznego, w szczególności koniecznością ochrony wierzycieli spółki. Tego typu środek jest właściwy,

${ }^{23}$ Por. A. Opalski, w: Kodeks spótek handlowych, t. 3B: Spótka akcyjna. Komentarz art. 393490, Warszawa 2016, s. 1228-1229 (Nb 12) i cytowana tam literatura.

${ }^{24}$ Przeniesienie siedziby statutowej jest ele mentem procedury transgranicznego przekształcenia (reinkorporacji). M. Szydło, Przeniesienie siedziby statutowej za granice, „Rejent” 2008, z. 7-8, s. 130; J. Napierała, Transgraniczne przekształcenie spótki, w: Problemy polskiego i europejskiego prawa prywatnego, w: K. Klafkowska-Waśniowska et al. (red.), Księga pamiatkowa Profesora Mariana Kepińskiego, Warszawa 2012, s. 79; A. Opalski, op. cit., s. 1234 (Nb 20).

${ }^{25}$ Teza 113 wyroku ETS z 16 grudnia 2008 r., C-210/06 (Cartesio).

${ }^{26}$ Teza 132 wyroku ETS z 30 września 2003 r., C-167/01 (Inspire Art); teza 92 wyroku ETS z 5 listopada 2002 r., C-208/00 (Überseering).

${ }^{27}$ M. Mataczyński, Transgraniczne przeniesienie siedziby statutowej polskiej spótki handlowej zagranicę, „Problemy Prawa Prywatnego Międzynarodowego” t. 13 (red. M. Pazdan), Katowice 2013 , s. 52.

${ }^{28}$ Teza 23 wyroku ETS z 21 kwietnia 2005 r., C-140/03 (Komisja v. Grecja), w której Trybunał powołuje się na tezę 32 wyroku ETS z 31 marca 1993 r., C-19/92 (Kraus) oraz tezę 37 wyroku ETS z 30 listopada 1995 r., C-55/94 (Gebhard). 
ponieważ stanowi jedyną gwarancję ochrony interesów wierzycieli, wspólników i pracowników przekształcanej spółki. Interesów tych nie da się bowiem zabezpieczyć w mniej dolegliwy sposób, a to z uwagi na brak przepisów (prawa materialnego) regulujaccych procedurę transgranicznego przekształcenia. W szczególności takiej ochrony nie zabezpieczają próby stosowania wobec transgranicznego przekształcenia polskich przepisów dotyczących przekształceń krajowych (art. 551-584 ${ }^{13}$ k.s.h.) ${ }^{29}$.

Natomiast w mym przekonaniu godne ochrony interesy wierzycieli i wspólników krajowej spółki przekształcanej mogą być wystarczająco chronione przez - stosowane do transgranicznego przekształcenia per analogiam - przepisy Kodeksu spółek handlowych o przekształceniu spółek krajowych oraz o transgranicznym łączeniu się spółek ${ }^{30}$. Poza tym w wielu sytuacjach interes wierzycieli i wspólników spółki przekształcanej chronią także przepisy prawa unijnego.

\section{Ochrona interesów wierzycieli i wspólników spółki transgranicznie przekształcanej na gruncie prawa polskiego}

\subsection{Umożliwienie przeprowadzenia transgranicznego przekształcenia jako konsekwencja zasady skuteczności}

Państwa członkowskie zobowiązane są do zapewnienia skutecznej ochrony prawnej w dziedzinach objętych prawem Unii (art. 19 ust. 1 zd. 2 TUE ${ }^{31}$ ). Zarówno z wyroku w sprawie Sevic Systems, jak i z wyroku w sprawie Vale wynika, że przewidziane w prawie krajowym postacie restrukturyzacji nie powinny być zamknięte dla spółek z innych państw członkowskich. Brak przepisów o transgranicznym przekształceniu utrudnia, ale nie uniemożliwia przeprowadzenia tego typu restrukturyzacji bez konieczności likwidacji spółki i zakładania jej na nowo. Myśl ta z perspektywy państwa, do którego spółka imigruje, wyrażona została w wyroku w sprawie $V_{a l e^{32}}$, a z perspektywy państwa, z którego spółka emigruje - w wyroku w sprawie Cartesio ${ }^{33}$. Wynika to także z zasady skutec zności (principle of effectiveness), w myśl której przepisy krajowe nie powinny ani uniemożliwiać, ani nadmiernie utrudniać wykonywania praw przyznanych prawem unijnym (tu: prawa do transgranicznego przekształcenia jako postaci swobody przedsiębiorczości). Reguła ta - traktowana nie tylko jako zakaz utrudniania, lecz także jako nakaz pozytywnego działania ${ }^{34}$ - skierowana jest zarówno do państwa spółki przekształconej,

${ }^{29}$ M. Mataczyński, op. cit., s. 54.

30 J. Napierała, Europejskie prawo spótek. Prawo spótek Unii Europejskiej z perspektywy prawa polskiego, Warszawa 2013, s. 324; K. Oplustil, Transgraniczne przeksztatcenia i podziały spółek w świetle prawa europejskiego i polskiego, „Kwartalnik Prawa Prywatnego” 2014, z. 1, s. 101105 oraz 116-123.

${ }^{31}$ Traktat o Unii Europejskiej - wersja skonsolidowana (Dz. Urz. UE C 326 z 26 października 2012 r., s. 13).

32 Teza 38 wyroku TS z 12 lipca 2012 r., C-378/10 (Vale).

${ }^{33}$ Teza 111-112 wyroku ETS z 16 grudnia 2008 r., C-210/06 (Cartesio).

${ }^{34}$ Ch. Teichmann, Der Grenzüberschreitende Formwechsel ist spruchreif: das Urteil des EuGH in der Rs. Vale, „Der Betrieb” 2012, z. 37, s. 2091; J. Napierała, Europejskie..., s. 423; K. Oplustil, T. Włudyka, Grenzüberschreitender Herausformwechsel einer polnischen Kapitalgesellschaft im 
jak i państwa spółki przekształcanej. W braku czternastej dyrektywy interesy wierzycieli i wspólników polskiej spółki przekształcanej w spółkę zagraniczną chronić należy przez stosowanie przepisów o wewnętrznych przekształceniach oraz o transgranicznym łączeniu się spółek per analogiam $\mathrm{z}$ uwzględnieniem następujących reguł:

Po pierwsze - zastosowanie mogą znaleźć tylko środki ochrony uregulowane $\mathrm{w}$ przepisach adresowanych do wierzycieli i wspólników spółek kraj ow y ch. Przy transgranicznym przekształceniu spółki polskiej nie mogą być więc stosowane polskie przepisy chroniące interesy wierzycieli i wspólników ex post (tj. po dniu przekształcenia). W stosunku do zagranicznej spółki „przekształconej" nie znajdą więc zastosowania przepisy o oddzielnym zarządzaniu (art. 495 k.s.h.) oraz o pierwszeństwie zaspokojenia z majątku pierwotnej dłużniczki (art. 496 k.s.h.). Przy transgranicznym przekształcaniu polskiej spółki odpowiednie zastosowanie mógłby natomiast znaleźć art. $516^{10} \S 2$ k.s.h., zgodnie z którym wierzyciel spółki krajowej może żądać zabezpieczenia swoich roszczeń, jeżeli uprawdopodobni, że ich zaspokojenie jest zagrożone przez transgraniczne przekształcenie (ochrona ex ante); inna sprawa, że spółka przekształcona (zagraniczna), jako „kontynuatorka” spółki krajowej, może być zobowiązana do udzielenia zabezpieczenia wówczas, jeżeli krajowa spółka przekształcana nie wywiąże się ze swego zobowiązania, a spór nie zakończy się przed dniem przekształcenia ${ }^{35}$. Wattpliwości związane z realizacją ochrony wspólników mniejszościowych na podstawie art. 565 k.s.h. przemawiają za analogicznym stosowaniem art. $516^{11} \S 1$ k.s.h.; jeżeli więc spółką przekształcona jest spółka zagraniczna, wspólnik spółki krajowej, który głosował przeciwko uchwale o połączeniu i zażądał zaprotokołowania, może żądać odkupu jego udziałów lub akcji ${ }^{36}$.

Po drugie - krajowe przepisy powinny być stosowane po to, by chronić uzasadnione interesy wierzycieli i wspólników mniejszościowych spółki przekształcanej w sposób adekwatny do sytuacji, a więc tylko wówczas, jeżeli w konkretnym przypadku jest to konieczne. Stosując analogicznie art. $516^{10}$ $\S 2$ k.s.h. ${ }^{37}$, nie można np. traktować jako uprawdopodobnionego zagrożenia zaspokojenia wierzytelności tylko okoliczności, że spółka dłużnik przekształciła się w spółkę zagraniczna ${ }^{38}$. Takie uprawdopodobnienie mogłoby natomiast wystapić wówczas, gdy przekształcenie połączone jest z przemieszczeniem się za granicę istotnych składników majątkowych ${ }^{39}$.

\footnotetext{
Lichte der neuston Rechtsprechung des EuGH, w: Privatrecht, Wirtschaftsrecht, Verfassungsrecht. Privatinitiative und Gemeinwohlhorizonte in der europäischen Integration, Festschrift für Peter-Christian Müller-Graff zum 70. Geburtstag AM 29. Settember 2015, Baden-Baden 2015, s. 300.

${ }^{35}$ A. Opalski, Europejskie prawo spótek, Warszawa 2010, s. 467.

${ }^{36} \mathrm{~K}$. Oplustil, Transgraniczne przeksztatcenia i podziały spótek $w$ świetle prawa europejskiego i polskiego, „Kwartalnik Prawa Prywatnego” 2014, z. 1, s. 119-120.

${ }^{37}$ K. Oplustil, op. cit., s. 122-123.

${ }^{38}$ S. Otte, K. Rietschel, Freifahrschein für den grenzüberschreitenden Rechtsformwechsel, „GmbH-Rundschau” 2009, z. 18, s. 986.

${ }^{39}$ S. Otte, K. Rietschel, op. cit., s. 986; T. Frobenius, „Cartesio”: Partialle Wegzugsfreiheit für Gesellschaften in Europa, „Deutsches Steuerrecht” 2009, z. 10, s. 489.
} 


\subsection{Ochrona interesów wierzycieli i wspólników spółki przekształcanej w prawie unijnym}

Również regulacje prawa unijnego w znacznym stopniu łagodzą obawy o naruszenie interesów wierzycieli i wspólników spółki przenoszącej za granicę swą siedzibę statutową. Chodzi o obawy spowodowane zmianą dotychczasowego prawnego reżimu (a) jurysdykcyjnego w sprawach cywilnych, handlowych oraz (b) w postępowaniu upadłościowym, (c) zmianę prawa właściwego dla stosunków zobowiązaniowych łączących spółkę przekształcaną z jej wierzycielami oraz (d) zmianę statutu personalnego spółki.

\subsubsection{Jurysdykcja w sprawach cywilnych i handlowych}

Prawdą jest, że ze względu na zasadę ogólną międzynarodowego postępowania cywilnego (actor sequitur forum rei) wierzyciele spółki przenoszącej swą siedzibą statutową do innego państwa członkowskiego mogą być zmuszeni „do dochodzenia swoich roszczeń od spółki przed sądem obcego państwa" ${ }^{40}$. Biorąc jednak pod uwagę interes wierzyciela spółki transgranicznie przekształcanej - powyższa reguła wymaga uzupełnienia:

Po pierwsze - rozporządzenie $\mathrm{nr} 1215 / 2012^{41}$ zawiera autonomiczną definicję „miejsca zamieszkania” spółki - wskazuje alternatywnie miejsce: (1) siedziby statutowej, (2) głównego organu zarządzającego lub (3) głównego przedsiębiorstwa (art. 63 ust. 1). Znawcy przedmiotu podkreślaja, że na mocy tego przepisu - jeżeli wymienione „siedziby” spółki znajdują się w różnych państwach - może być ona pozywana zgodnie z wolą powoda w jednym z tych państw ${ }^{42}$. Ergo - w przypadku transgranicznego przekształcenia spółki bez przeniesienia jej „głównego przedsiębiorstwa” interes wierzycieli pozywających spółkę nie zostanie naruszony.

Po drugie - pomijajacc to, że w umowach gospodarczych z reguły znajduje się klauzula jurysdykcyjna, to przecież (w najczęściej w praktyce zawieranych umowach) sytuacja „starych” wierzycieli nie zmieni się, ponieważ właściwym z reguły pozostanie nadal (jako sąd miejsca krajowej spółki „przekształcanej”): (a) albo sąd miejsca dostarczenia rzeczy ruchomych bądź miejsca świadczenia usługi (art. 7 pkt 1 rozporządzenia nr 1215/2012), (b) albo (w sprawach dotyczaccych czynu niedozwolonego) sąd miejsca, w którym nastapiło lub może nastapić zdarzenie wywołujące szkodę (art. 7 pkt 2 rozporządzenia nr 1215/2012), czyli - jak to ujmuje Trybunał Sprawiedliwości - miejsca „w którym powiązane są działalność prowadzona przez [...] spółkę oraz sytuacja

${ }^{40}$ M. Mataczyński, op. cit., s. 52.

${ }^{41}$ Rozporządzenie Parlamentu Europejskiego i Rady (UE) nr 1215/2012 w sprawie jurysdykcji i uznawania orzeczeń sądowych oraz ich wykonywania w sprawach cywilnych i handlowych (Dz. Urz. UE z 20 września 2012, nr L 351, s. 1).

${ }^{42} \mathrm{~K}$. Weitz, Jurysdykcja krajowa oraz uznawanie $i$ wykonywanie orzeczeń $w$ sprawach cywilnych i handlowych w świetle prawa wspólnotowego, „Kwartalnik Prawa Prywatnego” 2004, z. 1, s. 220; P. Grzegorczyk, Zagraniczne spótki handlowe w europejskim prawie procesowym cywilnym, w: M. Cejmer, J. Napierała, T. Sójka (red.), Europejskie prawo spótek, t. 4: Spótki zagraniczne $w$ Polsce, Warszawa 2008, s. 170-171. 
finansowa związana z tą działalnością" ${ }^{3}$. Zdaniem Trybunału przed tym sądem wierzyciele mogą również wytaczać powództwa zmierzające do pociagnięcia do odpowiedzialności za długi spółki członka zarządu spółki oraz jej akcjonariusza, którzy pozwolili na dalszą działalność spółki, mimo że powinna była zostać postawiona w stan likwidacji ${ }^{44}$. Właściwość sądu miejsca zdarzenia wywołującego szkodę Trybunał sugeruje także w przypadku dochodzenia przez wierzyciela roszczenia od spółki zagranicznej mającej status akcjonariusza większościowego z powodu naruszenia ustawowego obowiązku informacyjnego (aktualizującego się przy przekroczeniu określonego progu większościowego) ${ }^{45}$.

Z kolei w sprawach dotyczących umowy (lub roszczenia z umowy), którą zawarł kons ument (art. 17 ust. 1 rozporządzenia nr 1215/2012 $2^{46}$ ) - konsument może wytoczyć powództwo przeciwko swojemu kontrahentowi przed sądem miejsca, w którym konsument ma miejsce zamieszkania, natomiast jego kontrahent musi wytoczyć powództwo przeciwko konsumentowi przed są dem miejsca jego zamieszkania (art. 18 rozporządzenia nr 1215/2012).

\subsubsection{Jurysdykcja w postępowaniu upadłościowym}

Zgodnie z art. 3 ust. 1 rozporządzenia nr 1346/2000 ${ }^{47}$ sądy państwa członkowskiego, na terytorium którego znajduje się główny ośrodek podstawowej działalności dłużnika, są właściwe dla wszczęcia postępowania upadłościowego. W przypadku spółek i osób prawnych domniemywa się, że głównym ośrodkiem ich podstawowej działalności jest siedziba określona w statucie, chyba że zostanie przeprowadzony dowód przeciwny ${ }^{48}$. W swej opinii w spra-

${ }^{43}$ Teza 2 sentencji wyroku TSUE z 18 lipca 2013 r., C-147/12 (ÖFAB, Östergötlands Fastigheter $A B$ ). Właściwym do rozpoznania sprawy nie był sąd miejsca zamieszkania członka zarządu, lecz sąd tego państwa członkowskiego, w którym spółka prowadziła działalność gospodarczą i wybudowała hotel: „[...] okazuje się, że prowadzona działalność, a także sytuacja finansowa związana z tymi czynnościami, są powiązane z tym miejscem” (teza 54).

${ }^{44}$ Teza 1 sentencji wyroku TSUE z 18 lipca 2013 r., C-147/12 (ÖFAB, Östergötlands Fastigheter $A B$ ). W uzasadnieniu tego wyroku Trybunał zwraca uwagę: po pierwsze - ,art. 1 ust. 2 lit. b) rozporządzenia nr 44/2001 wyklucza z zakresu jego zastosowania jedynie powództwa wytaczane bezpośrednio na podstawie postępowania upadłościowego i ściśle z nim związane" (teza 24); po drugie - wytoczenie spornych powództw w postępowaniu głównym nie wpisuje się w ramy postępowania upadłościowego [...]. W każdym razie [...] nie stanowi wyłącznych prerogatyw syndyka wykonywanych w interesie wierzycieli, lecz chodzi o prawa, które ÖFAB może wykonywać w swoim własnym interesie" (teza 25). Por. K. Osajda, Niewypłacalność spótki z o.o. Odpowiedzialność członków zarzqdu wobec jej wierzycieli, Warszawa 2014, s. 437-441.

${ }^{45}$ Teza 26 wyroku z 17 października 2013 r., C-519/12 (OTP Bank Nyilvánosan Müködő Részvénytársaság).

${ }^{46}$ Poprzednio art. 15 ust. 1-2 rozporządzenie Rady (WE) nr 44/2001.

${ }^{47}$ Rozporządzenie Rady (WE) nr 1346/2000 z 29 maja 2000 r. w sprawie postępowania upadłościowego (Dz. Urz. UE z 30 czerwca 2000 r., nr L 160, s. 1).

${ }^{48}$ Sądy państwa członkowskiego, na którego terytorium wszczęto postępowanie upadłościowe dotyczące majątku spółki, są także właściwe do rozpoznania powództwa wniesionego przez syndyka masy upadłości tej spółki przeciwko członkowi zarządu o zwrot kwot wypłaconych po wystapieniu niewypłacalności tej spółki lub po stwierdzeniu jej nadmiernego zadłużenia - teza 27 wyroku TSUE z 4 grudnia 2014 r. w sprawie C-295/13 (H v. H.K.). Prawo państwa członkowskiego, w którym zostaje wszczęte postępowanie upadłościowe, jest zarazem co do zasady p r a w e m właściwym dla postępowania upadłościowego i jego skutków (art. 4 ust. 1 rozporządzenia 
wie Interedil Srl rzecznik generalny podkreśla, że „konsekwencje przeniesienia siedziby [statutowej - uzup. J.N.] dla ustalenia właściwego sądu upadłościowego mogą być czasem niekorzystne dla wierzycieli, którzy nawiązali stosunki prawne z dłużnikiem w państwie, z którego przeniesiono siedzibę. Założenie dotyczące miejsca przeprowadzenia ewentualnego postępowania upadłościowego, z którego wychodzili wierzyciele w momencie nawiązania stosunków prawnych z dłużnikiem, okazuje się bowiem po przeniesieniu siedziby nietrafne. Uwzględnienie przeniesienia siedziby przy ustalaniu jurysdykcji prowadzi do tego, iż oczekiwania wierzycieli w państwie, z którego przeniesiono siedzibę, zostaną zawiedzione" ${ }^{49}$. Podzielając ten pogląd, należy dodać, że: po pierwsze - również w postępowaniu upadłościowym obowiązuje zasada perpetuatio iurisdictionis ${ }^{50}$, tzn. dla określenia właściwego sądu znaczenie ma położenie głównego ośrodka podstawowej działalności dłużnika w dacie złożenia wniosku o wszczęcie postępowania upadłościowego ${ }^{51}$; po drugie - pozostawienie w państwie emigracji funkcjonującego nadal przedsiębiorstwa stanowiącego materialną podstawę do utworzenia oddziału zagranicznej spółki przekształconej otwiera możliwość ogłoszenia wszczęcia „niezależnego postępowania ubocznego" ${ }^{2}$ bądź postępowania "wtórnego" ${ }^{53}$ (art. 3 ust. 2 i 4 rozporządzenia nr 1346/2000), które przebiegają zgodnie z krajowym prawem upadłościowym właściwym dla oddziału ${ }^{54}$.

\subsubsection{Prawo właściwe dla stosunków obligacyjnych}

Przeniesienie siedziby statutowej spółki wywiera wpływ na prawo właściwe dla stosunków obligacyjnych, ponieważ art. 4 rozporządzenia Parlamentu Europejskiego i Rady (WE) nr 593/2008 (Rzym I) ${ }^{55}$ uwzględnia zasadę właś-

nr 1346/2000). Zgodnie z tezą 1 sentencji wyroku TSUE z 10 grudnia 2015 r., C-594/14 (Simo$n a$ Kornhaas $v$. Thomasowi Dithmarowi, działajacemu $w$ charakterze syndyka masy upadtości spótki Kornhaas Montage und Dienstleistung Ltd) - zakres zastosowania art. 4 rozporządzenia nr 1346/2000 „obejmuje powództwo przeciwko osobie zarządzającej spółką prawa Anglii i Walii wobec której to spółki wszczęto postępowanie upadłościowe w Niemczech - wytoczone przed sądem niemieckim przez syndyka masy upadłości tej spółki, którego to powództwa celem jest, zgodnie $\mathrm{z}$ uregulowaniem krajowym takim jak $\S 64$ ust. 2 zdanie pierwsze GmbHG, doprowadzenie do zwrotu przez tę osobę płatności dokonanych przez nią jeszcze przed wszczęciem postanowienia upadłościowego, ale już po dacie, co do której ustalono, że przedmiotowa spółka jest niewypłacalna".

${ }_{49}$ Teza 45 opinii Rzecznika Generalnego (Juliane Kokott) z 10 marca 2011 r. w sprawie C-396/09 (Interedil Srl, w likwidacji).

${ }^{50}$ Teza 29 wyroku ETS z 17 stycznia 2006 r. w sprawie C-1/04 (Staubitz-Schreiber). A. Wowerka, Glosa, „Gdańskie Studia Prawnicze - Przegląd Orzecznictwa” 2010, nr 3-4, s. 211-221.

${ }^{51}$ Teza 55 wyroku C-369/09 (Interedil Srl, w likwidacji).

${ }^{52}$ Teza 18 wyroku TSUE z 17 listopada 2011 r. w sprawie (Procureur-generaal bij het hof van beroep te Antwerpen).

${ }^{53}$ Por. np. wyroku TSUE z 22 listopada 2012 r. w sprawie C-116/11 (Bank Handlowy $w$ Warszawie SA, PPHU „ADAX” Ryszard Adamiak); wyroku TSUE z 4 września 2014 r. w sprawie C-327/13 (Burgo Group SpA).

${ }^{54}$ Uchwała SN z 20 stycznia 2010 r., III CZP 115/09 (OSNC 2010, nr 7-8, poz. 106).

${ }_{55}$ Rozporządzenie Parlamentu Europejskiego i Rady (WE) nr 593/2008 z 17 czerwca 2008 r. w sprawie prawa właściwego dla zobowiązań umownych (Rzym I), Dz. Urz. UE L 177 z 4 lipca 2008, s. 6. 
ciwości prawa strony zobowiązanej do świadczenia charakterystycznego ${ }^{56}$. Należy jednak podkreślić, że: po pierwsze - w umowach gospodarczych zawieranych przez spółkę przekształcaną z reguły znajduje się (obok klauzuli jurysdykcyjnej) klauzula wyboru prawa wiążąca również zagraniczną spółkę przekształcona; po drugie - zmiana statutu obligacyjnego nie wpłynie na sytuację konsumentów, ponieważ obrót konsumencki na terenie UE został w znacznym stopniu zharmonizowany; po trzecie - wierzytelności spółki przekształcanej stają się wierzytelnościami spółki przekształconej w ich dotychczasowym kształcie (zasada kontynuacji), podobnie jak wierzytelności i inne składniki majątku spółki przejmowanej w wyniku transgranicznego łączenia się (zasada sukcesji generalnej) ${ }^{57}$. Teza o właściwości prawa dotychczasowego przy określaniu treści wierzytelności przejętej w drodze sukcesji generalnej (kontynuacji) oparta jest na wnioskowaniu z normy art. 14 ust. 2 rozporządzenia Rzym I (w zw. z art. 1 ust. 2 lit. f) regulującej prawo właściwe dla cesji wierzytelności; znajduje ona także wsparcie w opinii rzecznika generalnego (Yves'a Bota) w sprawie C-483/14 (KA Finanz AG), w której zaprezentowana została m.in. wykładnia art. 14 ust. 1 dyrektywy $2005 / 56 / \mathrm{WE}^{58}$.

\subsubsection{Statut personalny spółki}

Transgraniczne przekształcenie spółki nie prowadzi do istotnego pogorszenia sytuacji jej wierzycieli i (pozostających w spółce) wspólników w związku ze zmianą statutu personalnego spółki kapitałowej. Prawo akcyjne w dużym stopniu zostało na terenie Unii zharmonizowane, a ewentualny alternatywny w stosunku modelu ochrony kapitału zakładowego, spółki z o.o. (test bilansowy, test płynności finansowej), o ile nie poprawia, to w każdym razie nie pogarsza sytuacji dotychczasowych wierzycieli (wyrok w sprawie Inspire $\left.A r t^{59}\right)$.

\footnotetext{
${ }^{56}$ M. Mataczyński, op. cit., s. 52.

${ }^{57}$ Por. wyroku TSUE z 5 marca 2015 r., C-343/13 (Modelo Continente Hipermercados SA): ponoszenie przez spółkę przejmującą konsekwencji nałożonej na spółkę przejmowaną grzywny za naruszenie prawa pracy.

${ }^{58}$ Ponieważ zgodnie z art. 14 ust. 1 dyrektywy 2005/56 połączenie transgraniczne powoduje, poczynając od daty, w której połączenie to nabiera skutku, przeniesienie całości aktywów i pasywów ze spółki przejmowanej do spółki przejmującej; ta ostatnia spółka staje się następcą prawnym tej pierwszej na zasadach sukcesji uniwersalnej, przejmując w ten sposób ogół jej umów zawartych przed połączeniem, bez wprowadzania zmian. $\mathrm{Z}$ tego względu prawo wybrane przez strony w momencie zawarcia tych umów pozostaje prawem właściwym w sporze; $w$ tym przypadku jest to prawo niemieckie. Teza 47 opinii Rzecznika Generalnego (Yves'a Bota) z 12 listopada 2015 r. w sprawie C-483/14 (KA Finanz AG v. Sparkassen Versicherung AG Vienna Insurance Group).

${ }^{59}$ Wyrok ETS z 30 września 2003 r., C-167/01 (Kamer van Koophandel en Fabrieken voor Amsterdam v. Inspire Art Ltd).
} 


\section{TRANSGRANICZNE PRZEKSZTAŁCENIE A PRZENIESIENIE GLÓWNEGO PRZEDSIĘBIORSTWA SPÓŁKI PRZEKSZTALCANEJ}

Trybunał Sprawiedliwości podkreśla, że „pojęcie przedsiębiorczości w rozumieniu postanowień traktatu dotyczących swobody przedsiębiorczości zakłada faktyczne wykonywanie działalności gospodarczej poprzez stały zakład w tym państwie na czas nieokreślony [...]"60. Doktryna prawa sygnalizuje problemy wiążące się z ustaleniem spełnienia wymogu posiadania „stałego zakładu” (,stałej struktury”), w szczególności w dobie Internetu ${ }^{61}$. Praktyka próbuje te wątpliwości rozwiać albo wskazując kryteria ogólne ${ }^{62}$, albo przez rozstrzygnięcia ad casum: np. korzystanie przez podmiot gospodarczy z serwera - który fizycznie znajduje się w innym państwie członkowskim - nie oznacza, że podmiot ten prowadzi w tym państwie działalność gospodarczą ${ }^{63}$; z kolei - zdaniem Trybunału - spółka prawa brytyjskiego działająca we Włoszech korzysta ze swobody przedsiębiorczości: „ponieważ zawarła umowy handlowe z włoskimi podmiotami lub pośrednikami, na mocy których gromadzili oni i rejestrowali zakłady wzajemne zawierane przez konsumentów włoskich, po czym przekazywali je wspomnianej spółce”64.

„Stałej struktury” nie należy utożsamiać z siedziba faktyczną spółki. Co prawda w typowych sytuacjach transgraniczne przekształcenie (jako postać pierwotnego korzystania ze swobody przedsiębiorczości) łączy się z przeniesieniem siedziby władz spółki. Wymóg trwałej lokalizacji struktury decyzyjnej w państwie nowej siedziby statutowej spółki traci jednak na znaczeniu, jeżeli spółka zamierza - bezpośrednio po dokonaniu transgranicznego prze-

60 Teza 54 wyroku ETS z 12 września 2006 r., C-196/04, Cadbury Schweppes, Zb. Orz. 2006, s. I-7995. Rolę fakty c znej eks pans ji spółki do innego państwa członkowskiego TSUE wyraźnie wyeksponował także w wyroku w sprawie Vale.

61 Jaka intensywność prowadzenia działalności gospodarczej jest wymagana? W jakim momencie „stały zakład” powinien funkcjonować: chyba nie tylko przed rejestracją nowej siedziby statutowej spółki (np. jako wyposażenie oddziału)? Czy wystarczy oświadczenie o zamiarze prowadzenia działalności gospodarczej? A jakie wynikną konsekwencje, jeżeli - mimo deklarowanego zamiaru - działalność gospodarcza w państwie przyjmującym nie będzie prowadzona? Kto to miałby sprawdzać? A w jaki sposób sprawdzać wymóg prowadzenia działalności gospodarczej w państwie przyjmującym: czy od strony formalnej, badając wyposażenie (co łatwo obejść), czy materialnej, badając proporcje między działalnością gospodarczą w tym kraju a zagraniczną (co prowadzi no niepewności prawnej)? I wreszcie: czy w dobie Internetu w ogóle zasadny jest wymóg posiadania stałego zakładu, jeżeli celem transgranicznego przekształcenia jest przybranie formy prawnej spółki tego państwa, w którym znajduje się jej klientela? T. Drygala, Europäische Niederlassungsfreiheit vor der Rolle rückwärts?, „Europäische Zeitschrift für Wirtschaftsrecht” 2013, nr 15, s. 570-571.

${ }^{62}$ Zdaniem Trybunału wykonywanie działalności gospodarczej musi być możliwe do sprawdzenia na podstawie obiektywnych informacji, takich jak stopień fizycznej obecności określony posiadaniem lokalu, personelu i wyposażenia. Teza 67 wyroku z 12 września 2006 r., C-196/04 (Cadbury Schweppes plc, Cadbury Schweppes Overseas Ltd); teza 66 opinii Rzecznika Generalnego z 31 marca 2011 r. w sprawie C-347/09 (Bezirksgericht Linz przeciwko Jochenowi Dickingerowi i Franzowi Ömerowi). Z kolei w wyroku w sprawie Vale mowa jest o „zamiarze” prowadzenia przez spółkę włoską działalności na Węgrzech.

63 Teza 61 Rzecznika Generalnego z 31 marca 2011 r. w sprawie C-347/09 (Bezirksgericht Linz przeciwko Jochenowi Dickingerowi i Franzowi Ömerowi).

64 Teza 46 wyroku z 6 listopada 2003 r., C-243/01 (Gambelli i in.). 
kształcenia - przenieść swoją siedzibę faktyczną do państwa, z którego wyemigrowała. Poza tym, jeżeli państwo przyjmujące nie wymaga od swoich spółek lokalizacji na swoim terenie siedziby faktycznej (pozwala na rozszczepienie siedziby faktycznej i statutowej), to korzystanie przez spółkę przekształcaną ze swobody przedsiębiorczości może się ograniczyć do przeniesienia jej siedziby statutowej ${ }^{65}$.

W żadnym z wyżej wspomnianych wariantów transgranicznego przekształcenia nie jest wymagane przenoszenie głównego przedsiębiorstwa spółki przekształcanej. Taki wymóg byłby nieracjonalny w szczególności wówczas, gdy spółka ta - jako „przekształcona” - zamierza nadal prowadzić działalność gospodarczą w formie oddziału zlokalizowanego w państwie członkowskim, z którego emigruje.

\section{PODSUMOWANIE}

Uzależnienie wykreślenia z rejestru polskiej spółki kapitałowej przenoszącej swą siedzibę statutową do innego państwa członkowskiego w ramach transgranicznego przekształcenia od jej rozwiązania po przeprowadzeniu procedury likwidacyjnej - stanowi ograniczenie swobody przedsiębiorczości.

Godne ochrony interesy wierzycieli i wspólników krajowej spółki przekształcanej chronia - stosowane do transgranicznego przekształcenia per analogiam - przepisy k.s.h. o przekształceniu spółek krajowych oraz o transgranicznym łączeniu się spółek oraz, w wielu sytuacjach, przepisy prawa unijnego. Ich stosowanie uzasadnia zasady skuteczności rozumiana nie tylko jako zakaz uniemożliwiania i nadmiernego utrudniania wykonywania praw przyznanych prawem unijnym (tu: prawa do transgranicznego przekształcenia jako postaci swobody przedsiębiorczości), lecz także jako - skierowany zarówno do państwa spółki przekształconej, jak i państwa spółki przekształcanej - nakaz pozytywnego działania sprzyjającego korzystaniu przez spółkę ze swobody przedsiębiorczości.

Przeprowadzenie transgranicznego przekształcenia nie wymaga zmiany lokalizacji (przeniesienia) głównego przedsiębiorstwa spółki przekształcanej.

Przeniesienie siedziby statutowej umożliwiającej spółce przeprowadzenie transgranicznego przekształcenia powinno zostać uregulowane w czternastej dyrektywie. Na razie uzasadniony jest postulat de lege ferenda unormowania przez polskiego ustawodawcę transgranicznego przekształcenia albo przez odrębną regulację, albo przez stworzenie wyraźnej podstawy do odpowiedniego stosowania przepisów o przekształceniu spółek krajowych oraz przepisów o transgranicznym łączeniu się spółek.

prof. dr hab. Jacek Napierała

Uniwersytet im. Adama Mickiewicza w Poznaniu

jnapier@amu.edu.pl

${ }^{65}$ Teza 112 wyroku ETS z 16 grudnia 2008 r., C-210/06 (Cartesio). Por. J. Napierała, Uwagi na temat ksztattu planowanej dyrektywy $w$ sprawie transgranicznego przeniesienia siedziby spót$k i$, „Ruch Prawniczy, Ekonomiczny i Społeczny” 76, 2014, z. 4, s. 116. 


\section{CROSS-BORDER TRANSFER OF THE REGISTERED OFFICE \\ OF A POLISH COMPANY ABROAD AS A REASON FOR THE COMPANY'S DISSOLUTION IN LIGHT OF THE CODE OF COMMERCIAL PARTNERSHIPS AND COMPANIES AND FREEDOM OF ENTREPRENEURSHIP}

Sum mary

In the absence of a EU (fourteenth) directive on the transfer of a company's registered office, a number of questions arise including whether a Member State may prevent cross-border transfer of a company by enforcing a requirement that it be dissolved in a liquidation procedure. Article 270 point 2 and Article 459 point 2 of the Code of Commercial Partnerships and Companies provides for such a requirement stating that a shareholders' resolution to move a company abroad shall constitute a reason for dissolving the company. Hence a decision of the Supreme Court to refer to the European Court of Justice regarding compliance of this regulation with the Treaty on the European Union (Article 49).

It is generally expected that a fourteenth directive regulating the above matter will be issued. Sharing this expectation, the author attempted to provide rationale for the following de lege lata conclusions: (i) a situation in which the striking off a company's name from the Polish register of entrepreneurs if its registered office is to be cross-border transferred to another Member State is contingent upon such company's dissolution constitutes a limitation of the freedom of entrepreneurship and (ii) the interests of creditors and shareholders that are worthy of protection when a Polish company is being transformed (also when per analogiam applied in the case of a cross-border transfer) are protected by relevant provisions of the Polish Code of Commercial Partnerships and Companies as well as, frequently, the EU regulations, and (iii) a cross-border transformation does not require a change (or transfer) of the company's registered office.

In light of the above, a de lege ferenda postulate must be made calling for adoption of a separate regulation or an explicit provision constituting grounds for relevant application of provisions on the transformation of Polish companies and provisions on mergers. 